\title{
Eco-toxicological Effects of Pesticide Residues on Soil Biological Sentinels
}

\author{
ATUANYA, EI;*ONUOHA, T; MORKA, E \\ Department of Microbiology, University of Benin, Benin City, Nigeria \\ *Corresponding Author Email: onuohakelechi6@gmail.com
}

\begin{abstract}
This research studied the eco-toxicological effects of pesticide residues on soil biological sentinels. Nitrobacter and Nitrosomonas sp. was isolated from Soil samples gotten from dumpsite in Benin City and cultured using Winogradsky medium. The bacterial isolate was characterized and identified based on its cultural, morphological and biochemical characteristics. After 4 to 5 days of growth, Nitrobacter and Nitrosomonas Counts obtained from Winogradsky medium ranged from $1.87 \pm 0.95$ to $2.43 \pm 1.1 \times 10^{4} \mathrm{cfu} / \mathrm{g}$. The pesticides were observed to have negative effect on the growth of Nitrobacter and Nitrosomas sp. in broth culture media. The effective and lethal concentration $\left(\mathrm{EC}_{50}\right)$ and $\left(\mathrm{LC}_{50}\right)$ for each of the pesticides were observed to decrease with increase in the time of exposure and the effects of the two pesticides on both nitrite oxidations by Nitrobacter $\mathrm{sp}$. and ammonia oxidation by Nitrosomonas sp. were similar. The results also showed that earthworms had weight loss and death at different concentration of the pesticide and time of exposure, with the lethal concentration $\left(\mathrm{LC}_{50}\right)$ of aldrin being $2.84 \mathrm{mg} / \mathrm{ml}$ while that of lindane was $3.54 \mathrm{mg} / \mathrm{ml}$ after $48 \mathrm{hr}$ of exposure period. More so, the result obtained from this study suggest that autotrophic transformation by nitrifying bacteria and earthworm which enhances soil fertility (hence significant in crop production) may be hindered in an ecosystem polluted with these pesticide formulations, as nitrification processes will be reduced. Thus, more efforts should be geared at reducing the indiscriminate and illegal use of pesticides (banned or approved).
\end{abstract}

\section{DOI: https://dx.doi.org/10.4314/jasem.v22i10.07}

Copyright: Copyright $(2018$ Atuanya et al. This is an open access article distributed under the Creative Commons Attribution License (CCL), which permits unrestricted use, distribution, and reproduction in any medium, provided the original work is properly cited.

Dates: Received: 08September 2018; Revised: 12 October: 2018; Accepted: 23 October 2018

Keywords: Pesticide residues, nitrobacter sp, nitrosomonas sp, Winogradsky medium

Pesticides are plant protection products widely used in agriculture to control diseases and increase crop yield. Xenobiotics pesticides are a major cause for concern all over the world, given their persistence to their metabolite residues after degradation by artificial or natural means and adverse effects on the eco-biota (Chapman, 2002).Biological sentinels (Nitrifying bacteria and earthworm) activities in the soil are important for mineral and organic matter cycling in ecological systems, with thenitrogen cycle being crucial for all organisms (Katagi, 2010). Microbial nitrification and earthworm are indicator organisms in the soil that are pointer to soil contamination and pollution. Nitrification is a chemoautotrophic process carried out by two bacterial groups that oxidize ammonium to nitrite and nitrite to nitrate Fenchel et al., (1998). This process is important to the nitrate content in soil, which is the major source of nitrogen assimilated by higher plants and, thus, of considerable ecological and agricultural importance (Katagi, 2010). Earthworms (Apporectoda longa) represent a large fraction of soil living biomass in many temperate ecosystems and play important role in soil functioning. As ecosystem engineers, they influence organic matter dynamics, soil structure, and microbial community (Katagi, 2010). They actively participate in soil aeration, water infiltration and mixture of soil horizons, and they represent an important source of food for many other organisms like birds or moles Hong et al., (1999). Organochlorine pesticides are used by farmers without proper training on application and understanding of their toxic effects on the environments. More worrisome is the fact that reports have shown that many of these pesticides readily available to farmers are banned and illegal stockpiles Zhou et al., (2006). Residues of pesticides, upon entering the soil, becomes toxic to non-target biological sentinels organisms (Chapman, 2002).The aim of this study was to evaluate the toxicity effects of pesticide residues on soil biological sentinels

\section{MATERIALS AND METHODS}

Isolation and characterization of nitrifying bacteria: Soil samples were collected from dumpsite in Benin City for the isolation of Nitrifying bacteria (Nitrobacter and Nitrosomonas).Nitrobacter sp. and Nitrosomonas sp. were isolated from the soil samples using the method employed by (Ibiene and Okpokwasili,2011) respectively.Nitrobacter and Nitrosomonas sp was isolated using Winogradsky medium 1 and 11 (NH4)2SO4, 2.0g; K2HPO4, 1.0g; $\mathrm{MgSO} 4.7 \mathrm{H} 2 \mathrm{O}, 0.5 \mathrm{~g} ; \mathrm{NaCl}, 2.0 \mathrm{~g} \mathrm{FeSO} 4.7 \mathrm{H} 2 \mathrm{O}, 0.4 \mathrm{~g}$; 
CaCO3, 0.01g, Agar 15.0g; Distilled water 1000ml. The media was sterilized by autoclaving and aseptically dispersed into sterile Petri dished after cooling to about $45^{\circ} \mathrm{C}$.The Petri dishes were then inoculated with and incubated aerobically for 4 days at room temperature $\left(28 \pm 2^{\circ} \mathrm{C}\right)$. Further identification and characterization of pure cultures of the organisms was undertaken. The broth media used for isolation of the test organisms also served as diluents for producing the various pesticide concentrations.

Standard inocula: Discrete colonies from each of the different plates were sub-cultured into fresh media. These were transferred into slants and stored at $4^{0} \mathrm{C}$. The slant culture served as stock culture. The standard inocula were prepared from the stock culture. Each of the isolate was picked from the respective stock cultures and incubated at $28^{\circ} \mathrm{C}$ for 24 hours. One millimeter was transferred from the respective flasks and a ten-fold serial dilution was made up to 10-3. An amount $(0.1)$ of the $10^{-3}$ dilution was plated into Winogradsky agar plates. The plates were incubated at room temperature for 48 hours.

Characterization and identification of bacterial isolates: The bacterial isolate was characterized and identified based on its cultural, morphological and biochemical characteristics which includes: Gram staining, Motility Test, Catalase Test, Oxidase Test, Coagulase Test, Urease Test, Indole Test, Citrate utilization Test, Sugar fermentation Test, Nitrate Reduction (Cheesbrough, 2000).

Preparation of pesticide concentration for Toxicity Test: For the determination of the median lethal concentration $\left(\mathrm{LC}_{50}\right)$, pesticides concentrations (Aldrin and gamma lindane) of $4 \mathrm{mg} / \mathrm{ml}, 8 \mathrm{mg} / \mathrm{ml}$, $16 \mathrm{mg} / \mathrm{ml}$ and $20 \mathrm{mg} / \mathrm{ml}$ were prepared (Ibiene and Okpokwasili, 2011).The median effective concentration $\left(\mathrm{EC}_{50}\right)$ of test were determined with concentrations of $2 \mathrm{mg} / \mathrm{ml}, 4 \mathrm{mg} / \mathrm{ml}, 6 \mathrm{mg} / \mathrm{ml}, 8 \mathrm{mg} / \mathrm{ml}$, and $10 \mathrm{mg} / \mathrm{ml}$. A control experiment (without Aldrin and gamma lindane) were set up (Ibiene and Okpokwasili, 2011).

Nitrifying Bacteria Acute Toxicity Test: A volumetric flask containing $250 \mathrm{ml}$ of nutrient broth was aseptically poured into five (5) conical flasks with a control.The test pesticides (aldrin and gamma lindane) of various concentrations $(2,4,6,8$ and $10 \mathrm{mg} / \mathrm{ml})$ were added to determine the $\mathrm{EC}_{50}$ and another different concentration of pesticide $(4,8,12,16$ and $20 \mathrm{ml})$ was also prepared to determine the $\mathrm{LC}_{50}$. One mililitre (1ml) of bacteria (Nitrobacter and Nitrosomonas sp) standard inoculum were ascetically inoculated into each flask (Atuanya and Ekanem, 2008). Plates of
Winograsky media were inoculated by spread plate techniques (Ibiene and Okpokwasili, 2011) from the various inoculum of pesticide concentration after 1,2 , 3 and $4 \mathrm{~h}$ incubated at room temperature $\left(28 \pm 2^{\circ} \mathrm{C}\right)$ for 24H (Ibiene and Okpokwasili, 2011). The percentage inhibition of bacterial growth (log survival) were plotted against test concentration and the median effective $\left(\mathrm{EC}_{50}\right)$ and lethal concentration $\left(\mathrm{LC}_{50}\right)$ value was determined using the probit analysis.

Collection of earthworms: The earthworms were collected from farmland in Benin City, Edo state. The worms were collected according to the method by (Chapman, 2002). They were collected by digging and hand sorting from substances litres and were taken to the laboratory for identification. They were washed to remove soil particles and were left on moist filter paper for voiding. Earthworms were selected based on their maturity (shown by the presence of clitellum) and liveliness (active response when anterior segment is prodded) (Atuanya and Tudararo-Aherobo, 2014).

Chronic Toxicity of Pesticide residues on the growth and survival of Earthworm (Apporectoda longa): Once the earthworms were obtained, they were identified and maintained in the laboratory using the procedure described by (Ibiene and Okpokwasili, 2011). The identification method employed was that of (Chapman, 2002). Experimental procedure for test was conducted in accordance with the procedure detailed in (OECD, 2003). The selected worms were acclimatized for 1-7 days in the soil from the earthworms' habitat. During this period the worms were fed with cellulose. Cellulose was prepared in advance by shredding white kaolin based paper, followed by converting it to pulp by mixing with distilled water, and subsequently drying at $30^{\circ} \mathrm{C}$ for $48 \mathrm{H}$. The weights of the worms were between 15 and $20 \mathrm{mg}$. The test conditions used were: temperature 28 $\pm 2{ }^{\circ} \mathrm{C}$; light- dark cycles: 16 and 18 H.Earthworm species used in this study are ecologically relevant to the Niger Delta of Nigeria. A longa represent epigeic species (Macrophagons, litter-dwelling).The test earthworm was identified as Apporectoda longa with the following characterisitics; red-violet in colour, anterior black segment, a prolobous prostomium, 8$14 \mathrm{~cm}$ in length, about 149- 159 segments, a bar shaped tubertatis and an alternatively paired ternate genital turmescenes. Four (4) concentrations $(4 \mathrm{mg} / \mathrm{ml}$, $8 \mathrm{mg} / \mathrm{ml}, 16 \mathrm{mg} / \mathrm{ml}$ and $20 \mathrm{mg} / \mathrm{ml}$ ) of the test pesticides (aldrin and gamma lindane) were prepared. Five hundred grams $(500 \mathrm{~g})$ of soil were mixed with the various test concentrations of pesticide and $20 \mathrm{~g}$ of cellulose was added to the soil as food for the earthworm. These were manually homogenized and distilled water $(80 \mathrm{ml})$ was added to achieve 45 percent 
moisture content in one (1L) amber-coloured glass jars. A blank (control) containing cellulose, water and soil also prepared. Test tanks were prepared in triplicates per concentration. Prior to use for the test, chosen worms were stored for $24 \mathrm{H}$ on a damp filter to void contents of the control and test soil were allowed to ingest and burrow into the test medium. The distributions of individual earthworms among the test chambers were randomized and death was the primary criterion used in this test guideline to evaluate the toxicity of the test substance for $48 \mathrm{H}$ (Chapman, 2002). Earthworms in the test and control chambers were observed for $48 \mathrm{H}$ days and the number alive were recorded and dead ones removed. In addition to death, weight loss, behavioural symptoms and pathological symptoms were recorded. The median lethal concentration $\left(\mathrm{LC}_{50}\right)$ were determined using probit analysis.

\section{RESULTS AND DISCUSSION}

The results from this research showed that the soil samples gotten from two different locations in dumpsite in Benin City all tested positive for the presence of Nitrobacter and Nitrosomonas sp. After 45 days of growth, the following counts were recorded on the growth medium as shown in (Table 1a). Cultural, biochemical and morphological characteristics are shown in (Table 1b). Tables ( $2 a$ and $2 b),(3 a$ and $3 b)$ and (4) shows the median effective $\left(\mathrm{Ec}_{50}\right)$ and lethal $\left(\mathrm{Lc}_{50}\right)$ concentration of Nitrobacter and Nitrosomonas sp and earthworm for the test pesticides after $4 \mathrm{H}$ exposure period.

Table 1a;Mean Bacterial counts of soil samples on winogradsky agar

\begin{tabular}{ll}
\hline Samples & Mean counts $\left(\mathbf{x 1 0} \mathbf{4}^{\mathbf{c}} \mathbf{c u} / \mathbf{g}\right)$ \\
\hline $\mathrm{A}$ & $1.87 \pm 0.95$ \\
$\mathrm{~B}$ & $2.43 \pm 1.13$ \\
\hline
\end{tabular}

The two isolates Nitrosomonas and Nitrobabacter sp isolated from dumpsite in Benin City, Edo State, with their cultural, morphological and biochemical reactions has been demonstrated. The study revealed the bacteria mean count of $1.87 \pm 0.95$ and $2.43 \pm 1.13$ from both soil samples. The results are in conformity with earlier reports of (Ibiene and Okpokwasili, 2011).

The results of toxicity studies showed that the toxicity of the Aldrin and Lindane, formulations on Nitrobacter sp. and Nitrosomonas sp. depended on the contact time and pesticide concentrations. The $\mathrm{EC}_{50}$ values for Nitrobacter sp. and Nitrosomonas sp. decreased with increase in exposure time for all the test pesticides (Table 2a and 3a). The decrease in $\mathrm{EC}_{50}$ with time may be attributed to increased water solubility with time. Probit analyses showed that the median effective concentration $\left(\mathrm{EC}_{50}\right)$ of the two pesticides for Nitrobacter sp. and Nitrosomonas sp. have an inhibitory and regression effect.

Table 1b.Cultural, Morphological and Biochemical Characteristics

\begin{tabular}{lll}
\multicolumn{3}{c}{ of the two isolates. } \\
\hline Characteristics & Isolate 1 & Isolate 2 \\
\hline Cultural & Round & Round \\
Shape & Raised & Raised \\
Elevation & Entire & Entire \\
Margin & Wet & Wet \\
Wetness/dryness & Opaque & Opaque \\
Transparency & Brownish & Cream \\
Colour & Small & \\
Size & & \\
Morphological & - & \\
Gram staining & Rod & \\
Cell type & Single & \\
Cell arrangement & - & - \\
Motility & & \\
Biochemical & + & + \\
Catalase & - & - \\
Oxidase & - & - \\
Coagulase & - & - \\
Urease & - & - \\
Indole & + & - \\
Citrate & - & - \\
Nitrate reduction & + & - \\
Ammonium reduction & + & A (+) \\
Sugar fermentation & & A (+) \\
Glucose & - & sp. \\
Lactose & Nitrosomonacter \\
Possible isolates & sp. & \\
& \multicolumn{1}{c}{ KEY: + = Positive reaction, -= Negative reaction } \\
& &
\end{tabular}

Table 2a: Median effective concentrations ( $\mathrm{EC}_{50}$ ) of the test pesticides for Nitrobacter $s p$. during a $4 \mathrm{~h}$ exposure

\begin{tabular}{lll}
\hline $\begin{array}{l}\text { Period } \\
\text { Time (hr) }\end{array}$ & \multicolumn{2}{c}{ Mean $\mathbf{E C}_{50}$ value $(\mathbf{m g} / \mathbf{m l})$} \\
\hline 1 & 17.79 & Lindane \\
2 & 18.86 & 15.82 \\
3 & 10.18 & 13.79 \\
4 & 9.14 & 9.48 \\
\hline
\end{tabular}

Table 2b: Median Lethal concentrations ( $\mathrm{LC}_{50}$ of the test pesticides for Nitrobacter $s p$. during a $4 \mathrm{~h}$ exposure

\begin{tabular}{lll}
\hline $\begin{array}{l}\text { Period } \\
\text { Time (hr) }\end{array}$ & \multicolumn{2}{c}{ Mean $\mathbf{L C}_{\mathbf{5 0}}$ value $(\mathbf{m g} / \mathbf{m l})$} \\
\hline 1 & 43.60 & Lindane \\
2 & 21.88 & 21.70 \\
3 & 21.71 & 18.70 \\
4 & 16.64 & 11.57 \\
\hline
\end{tabular}

Table 3a: Median effective concentrations $\left(\mathrm{EC}_{50}\right)$ of the test pesticides for Nitrosomonas sp. during a $4 \mathrm{~h}$ exposure period

\begin{tabular}{lll}
\hline $\begin{array}{l}\text { Period } \\
\text { Time (hr) }\end{array}$ & \multicolumn{2}{c}{ Mean $\mathbf{E C}_{50}$ value $(\mathbf{m g} / \mathbf{m l})$} \\
\hline 1 & 13.02 & Lindane \\
2 & 14.84 & 15.17 \\
3 & 14.84 & 16.90 \\
4 & 6.69 & 3.65 \\
\hline
\end{tabular}

The low $\mathrm{EC}_{50}$ exhibited by the pesticides indicated that interference with enzyme activity was a mode of action of the two pesticides. The inhibition of enzyme activities by pesticides has been documented. (Brethour and Weersink, 2001) observed that aldrin at $100 \mu \mathrm{g} / \mathrm{l}$ and $200 \mu \mathrm{g} / \mathrm{l}$ inhibited the enzyme responsible 
for the metabolism of pentose and tricarboxylic acid cycle intermediates in Rhizobium sp. The activities of succinate dehydrogenase and reduced nicotimamide adenine dinucleotide (NAD) dehydrogenase in $B$. subtilis and $E$. coli were inhibited by chlordane Celik et al., (1995). Similarly, the $\mathrm{LC}_{50}$ decreased with increase in exposure time for all the test pesticides (Table $2 b$ and $3 b$ ).

Table 3b: Median lethal concentrations $\left(\mathrm{LC}_{50}\right)$ of the test pesticides for Nitrosomonas sp. during a $4 \mathrm{~h}$ exposure

\begin{tabular}{lll}
\hline Period & \multicolumn{2}{c}{ Mean LC $_{50}$ value $(\mathbf{m g} / \mathbf{m l})$} \\
\cline { 2 - 3 } Time $(\mathbf{h r})$ & Aldrin & Lindane \\
\hline 1 & 23.20 & 17.80 \\
2 & 28.93 & 19.07 \\
3 & 14.73 & 16.64 \\
4 & 13.53 & 13.92 \\
\hline
\end{tabular}

Lars (2000) have reported that increasing concentrations of organochlorine pesticides, reduced total viable count of marine bacteria while (Katagi, 2010) reported that treatment of B. subtilis with DDT resulted in alteration of membrane lipid composition. Inhibition of cell division in S. cerevisae by chlordane, heptachlor, aldrin and dieldrin has also been reported (Pimentel, 2009). Probit analyses showed that the median lethal concentrations $\left(\mathrm{LC}_{50}\right)$ of the two pesticides for Nitrobacter sp. and Nitrosomonas sp. decreased their growth thus: Aldrin $>$ Lindane. It also indicated that aldrin within the exposure time limit, inhibited growth of Nitrobacter sp. and Nitrosomonas sp. more than lindane. Hong et al., (1999) in their study observed that chlorothalonil at the field rate had a slight inhibitory effect on one soil only out of six. Conversely, chlorothalonil at higher rates inhibited nitrification significantly in all soils.

However, the sensitivities of populations of Nitrobacter and Nitrosomonas sp. to the two pesticides reveals that Nitrobacter sp. was more sensitive to aldrin than Nitrosomonas sp. while both bacterial populations showed similar sensitivities to lindane during the exposure period. Additionally, the analysis revealed that the effects of the two pesticides on both nitrite oxidations by Nitrobacter sp. and ammonia oxidation by Nitrosomonas sp. were similar. The work of (Pimentel, 2009) indicated that xylene was more toxic to Nitrosomonas sp. than Nitrobacter sp. Although both bacteria may have similar cell wall morphology as Gram-negative rods Hamilton et al., (2004), the difference in response of these bacteria to the pesticides may be due to genetic differences (Pimentel, 2009).

Comparison of the $\mathrm{LC}_{50}$ and $\mathrm{EC}_{50}$ of the two pesticides for Nitrobacter sp. and Nitrosomonas sp. revealed that the $\mathrm{EC}_{50}$ values were significantly lower than the $\mathrm{LC}_{50}$ values. This indicated that the $\mathrm{EC}_{50}$ determination was more sensitive than the $\mathrm{LC}_{50}$ determination. This observation is in conformity with earlier reports of (Katagi, 2010).

Table 4: Median lethal concentrations $\left(\mathrm{LC}_{50}\right)$ of the test pesticides for earthworm (Apporectoda longa) during a $48 \mathrm{~h}$ exposure period

\begin{tabular}{llc}
\hline Time $(\mathbf{H})$ & \multicolumn{2}{l}{ Mean valueLC $\mathbf{C}_{\mathbf{5 0}}(\mathbf{m g} / \mathbf{m l})$} \\
\cline { 2 - 3 } & Aldrin & Lindane \\
48 & 2.84 & 3.54 \\
\hline
\end{tabular}

The ecotoxicological effect of two pesticides aldrin and lindane on the earthworm (Apporectoda longa) harvested from farmland in Benin City has been studied. Earthworms (Apporectoda longa) represent a large fraction of soil living biomass in many temperate ecosystems and play important role in soil functioning. As ecosystem engineers, they influence organic matter dynamics, soil structure, and microbial community (Katagi, 2010). They actively participate in soil aeration, water infiltration and mixture of soil horizons, and they represent an important source of food for many other organisms like birds or moles Hong et al., (1999). (Holland and Sinclair, 2004) reported the importance of earthworms for assessing the general impact of pollution in soil. Since then, earthworm has been used as good bioindicators for soil quality and environmental impacts of cropping systems and pollutant (Holland, 1994). The toxicity report in this study revealed that the lethal concentration $\left(\mathrm{LC}_{50}\right)$ of aldrin is $(2.84 \mathrm{mg} / \mathrm{ml})$ (Table 4) while that of lindane is $(3.54 \mathrm{mg} / \mathrm{ml})$ when subjected to probit analysis after 48 hour of exposure period. Lindane was found ecologically to be more toxic because $\mathrm{LC}_{50}$ of aldrin was lower. The lethal effect (loss of weight and death) on the earthworm could be attributed to the type, concentration and period of exposure. Previous report by Hong et al., (1999) indicated that pesticides are toxic, disrupts enzymatic activities, affect survival, reproduction, increase individual mortality, decrease fecundity and growth, change individual behaviour such as feeding rate and decrease the overall community biomass, density and generally leads to loss of biodiversity. This is in consonance with the reports of (OECD, 2000); (Atuanya and Tudararo-Aherobo, 2014). In another work done by (Fernndez-Alba and Garca-Reyes , 2008) report also showed that individual, population levels, life- history traits, population density and behavior) and the community level: community biomass and density of the earthworms were negatively affected by DDT and lindane at all levels.

Conclusion: The result obtained from this study suggest that autotrophic transformation by nitrifying bacteria and earthworm which enhances soil fertility 
(hence significant in crop production) may be hindered in an ecosystem polluted with these pesticide formulations, as nitrification processes will be reduced.

\section{REFERENCES}

Atuanya, EI; Tudararo-Aherobo, L (2014). Ecotoxicological effects of discharge of Nigerian petroleum refinery oily sludge on biological sentinels. Afr. J. Environ. Sci. Technol. 9(2):95103.

Celik, S., Kunc, S., Asan, T (1995). Degradation of some pesticides in the field and effect of processing. Analyst. 120: 1739 - 1743.

Chapman, PM (2002). Integrating toxicology and ecology: putting the "eco" into ecotoxicology. Mar Pollution Bulletin, 44: 7-15.

Cheesbrough, M (2000). Microbiological test: District laboratory practice in tropical countries. Part 2. Cambridge University Press, New York, USA 447pp.

Fenchel, T., King, G M., Blackburn, TH (1998), Bacterial biogeochemistry: theecophysiology of mineral cycling, 2nd ed. Academic Press.
Hanazato, T., Hirokawa, H (2004). Changes in vulnerability of Daphnia to an insecticide application depending on the population phase. Freshwater. Bio.49: 402-409.

Holland, PT (1994). Effects of storage and processing on pesticide residues in plant products. Pure. Applied. Chem. 66 (2): 335 - 356.

Ibiene, AA; Okpokwasili, GSC (2011).Comparative toxicities of three agro-insecticide formulations on nitrifying bacteria. Report and Opinion. 3 (12):14-17

Katagi, T (2010). Bioconcentration, bioaccumulation, and metabolism of pesticides in aquatic organisms. Review of Environmental Contamination and Toxicology, 204: 1-132.

Pimentel, D (2009). Environmental and economic costs of the application of pesticides primarily in the United States. In: Peshin R, Dhawan (Eds). Integrated Pest Management: InnovationDevelopment Process. Springer Science, BerlinNew York, pp. 89-110 